Iplina A.A.

\title{
Reconstruction of Uzbek poetry image system in translation
}

Namangan State University (Uzbekistan, Namangan)

doi 10.18411/gq-30-11-2019-30

idsp sciencerussia-30-11-2019-30

\section{Abstract}

The article deals with the poetic system of images in the poetic speech of Uzbek lyrics on the material of the poem "Oshi halol" by the modern popular poet and translator Rustam Musurmon in the original language, as well as translations into English and Russian in a comparative aspect.

Key words: poetic image, imagery of speech, the area of meaning, the mechanism of text functioning, signal images.

As you know, one of the necessary components of the integrity of the poetic work is the imagery of the poem. Uzbek lyrics are characterized by extraordinary liveliness and colorfulness of the image. In one word or phrase Uzbek poets masterfully create images with specific representations of the pictures of life in the mind of the recipient. One of such kind of "masters of the word" is a modern poet and translator Rustam Musurmon. In the figurative series of his poetry a detail which was noticed only by the author can be traced, and which was not visible to anyone else until this moment.

For example, in his famous poem "Oshi halol" [1], a clear image is already presented in the title of the poetic work:

Poda qaytdi,

Qirda yonadi gulxan.

Podachi gulxanga yotib biryonbosh

Xurjundan chiqardi bitta ko'pgannon -

Ufqqa yonboshlab mudraydi quyosh...

Oshi halol,

Podachi,

Oshi halol!

Sovliqlar sog'ildi,

Qo'zilar yotdi.

Eshiklarni yopdi qo'rayu qo'rg'on.

Ovloq daralarning ko'zlari yondi -

Tosho'choqda qaynar bir qora qumg'on.

Oshi halol,

Podachi,

Oshi halol!

Rizqu ro'z beradi buloq, tog' $u$ tosh,

Odamning mol boqib topgan noni bol!

Osmonda porlaydi yulduzlar bosh-bosh,

Ko'kda poda boqib yuribdi hilol!

Oshi halol,

Podachi,

Oshi halol! 
"Oshi halol" (food earned by honest labor) - this leitmotif passes through the entire work of the author, therefore R. Musurmon repeats this metaphorical phrase after each quatrain by purpose, which contains the essence of the poem as a whole.

The description of the shepherd's life in his daily routine attracts the reader's attention and creates an incredible lightness of the poem, reaching the impression of immediacy: "Podachi gulxanga yotib biryonbosh Xurjundan chiqardi bitta ko'pgannon " - the shepherd lies down by the fire, takes unleavened bread out of a bag.

Here we can vividly observe the real picture in the boundless steppe: "Poda qaytdi, Qirda yonadi gulxan" - the herd has returned, a fire is burning in the steppe, "Sovliqlar sog'ildi, Qo'zilar yotdi" - the sheep are milked, lambs lie next to them," Tosho'choqda qaynar bir qora qumg'on " - in the hearth, made of stones, a smoked jug is boiling.

Also it is amazing how is the author chooses the words that embody the environment: "Ufqqa yonboshlab mudraydi quyosh" - the sun slumbers over the horizon, "Eshiklarni yopdi qo'rayu qo'rg'on" - the night mist closes the doors, "Ovloq daralarning ko'zlari yondi" - the eyes of the hunting gorge shine.

The mechanism of functioning of the text logically leads to the climactic denouement, where the author expresses the main idea of the content: "Odamning mol boqib topgan noni bol" - bread earned by his labor as honey.

In order to express true feelings, R. Musurmon reveals the area of the meaning of his poem, where in the last stanzas the semantic area of the divine prevails: "Osmonda porlaydi yulduzlar bosh-bosh, Ko'kda poda boqib yuribdi hilol" - in the sky the stars twinkle, in the sky the new moon grazes the herd. Here, the very meaning of the entire poetic work is superior to its utterance, which makes the semantic compatibility of the content polysemantic and multifaceted.

Thus, each element of the multilevel figurative system of this poetic work exists in a deep relationship of all components of the images of the context of the poem, which undoubtedly indicates a high level of skill of the poet.

Further, to compare the figurative structure of the original, we present the translations into Russian and English:

\section{Честный хлеб}

Дремлют овцы на просторе у костра

И пастух прилёг усталый у огня,

Съел лепешку и заснул он до утра...

Солнце тоже дремлет на закате дня.

Честным трудом

Живёт чабан,

Честным трудом!

Мгла ночная над степями и горами,

Свет один мерцает только в очаге,

Тишина стоит такая над стадами,

Лишь кумган ещё кипит на огоньке.

Честным трудом

Живёт чабан,

Честным трудом!

Влага вод нужна в засушливых местах, А пастуха лишь только труд его спасёт.

Юный месяц ночью каждой в небесах

Словно стадо миллионы звёзд пасёт.

Честным трудом

Живёт чабан,

Честным трудом! 


\section{Honest food}

A flock has come back.

In the steppe there is a fire,

A shepherd is lying down near it.

He takes bread out of his bag with strong desire...

The sun went down with its oppressive heat.

The honest food

Of shepherd,

The honest food!

The ewes has been milked,

The lambs are nearby.

The doors were shut by obscurity of night.

The shiny eyes of hunting gorge are very high,

A blackened jug is boiling on the right.

The honest food

Of shepherd,

The honest food!

The spring gives water,

The rocky hill - the stone.

The bread of hard work tastes as sweet as honey.

In the sky the new moon tends a herd alone,

The starry sheep are taking a long journey.

The honest food

Of shepherd,

The honest food!

Now let's compare a multi-level series of images of all three options, for a better understanding, we have highlighted the signal images in bold:

Level 1 - "the image of the shepherd", which expresses not only a specific person, but the whole of humanity in a broad philosophical sense:

\begin{tabular}{|c|l|c|}
\hline $\begin{array}{c}\text { Podachi gulxanga yotib } \\
\text { biryonbosh }\end{array}$ & И пастух прилёг усталый у огня & A shepherd is lying down near it \\
\hline
\end{tabular}

Level 2 - in the" image of bread" the author points to the results of fruitful work of a person who brings him pleasure:

\begin{tabular}{|c|c|c|}
\hline $\begin{array}{c}\text { Xurjundan chiqardi bitta } \\
\text { ko'pgannon }\end{array}$ & Съел лепешку и заснул он до & $\begin{array}{c}\text { He takes bread out of his bag with } \\
\text { strong desire }\end{array}$ \\
\hline $\begin{array}{c}\text { Odamning mol boqib topgan noni } \\
\text { bol }\end{array}$ & А пастуха лишь только труд его \\
спасёт & $\begin{array}{c}\text { The bread of hard work tastes as } \\
\text { sweet as honey }\end{array}$ \\
\hline
\end{tabular}

Level 3 - "existential images" create a scene surrounding the shepherd, that is, the atmosphere of his life:

\begin{tabular}{|c|c|c|}
\hline Poda qaytdi, Qirda yonadi gulxan & $\begin{array}{c}\text { Дремлют овцы на просторе y } \\
\text { костра }\end{array}$ & $\begin{array}{c}\text { A flock has come back. } \\
\text { In the steppe there is a fire }\end{array}$ \\
\hline Sovliqlar sog'ildi,Qo'zilar yotdi & - & $\begin{array}{c}\text { The ewes has been milked, } \\
\text { The lambs are nearby. }\end{array}$ \\
\hline $\begin{array}{c}\text { Tosho'choqda qaynar bir qora } \\
\text { qumg'on }\end{array}$ & $\begin{array}{c}\text { Лишь кумган ещё кипит на } \\
\text { огоньке }\end{array}$ & $\begin{array}{c}\text { A blackened jug is boiling on the } \\
\text { right }\end{array}$ \\
\hline
\end{tabular}


Level 4 - "images of the environment" take away from the hustle and bustle of everyday life, and show the relationship and interaction of nature and man:

\begin{tabular}{|c|c|c|}
\hline $\begin{array}{c}\text { Ufqqa yonboshlab mudraydi } \\
\text { quyosh }\end{array}$ & $\begin{array}{c}\text { Солнце тоже дремлет на закате } \\
\text { дня }\end{array}$ & $\begin{array}{c}\text { The sun went down with its } \\
\text { oppressive heat }\end{array}$ \\
\hline Eshiklarni yopdi qo'rayu qo'rg'on & $\begin{array}{c}\text { Мгла ночная над степями и } \\
\text { горами }\end{array}$ & $\begin{array}{c}\text { The doors were shut by obscurity } \\
\text { of night }\end{array}$ \\
\hline Ovloq daralarning ko'zlari yondi & $\begin{array}{c}\text { Свет один мерцает только в } \\
\text { очаге }\end{array}$ & $\begin{array}{c}\text { The shiny eyes of hunting gorge } \\
\text { are very high }\end{array}$ \\
\hline
\end{tabular}

Level 5 - "the image of the divine" in the author's idea embodies the theological idea that God keeps an eye on a human and the Lord leads him through life, under the necessary condition that a person will be honest in everything:

\begin{tabular}{|c|c|c|}
\hline $\begin{array}{c}\text { Osmonda porlaydi yulduzlar } \\
\text { bosh-bosh, Ko'kda poda boqib } \\
\text { yuribdi hilol }\end{array}$ & $\begin{array}{c}\text { Юный месяц ночью каждой в } \\
\text { небесах }\end{array}$ & $\begin{array}{c}\text { In the sky the new moon tends a } \\
\text { herd alone, }\end{array}$ \\
$\begin{array}{c}\text { Словно стадо миллионы звёзд } \\
\text { пасёт }\end{array}$ & $\begin{array}{c}\text { The starry sheep are taking a long } \\
\text { journey. }\end{array}$ \\
\hline
\end{tabular}

As can be seen from the comparative analysis of the original and translation images, the signal images were in most cases preserved in the translation into Russian and English. These signal images, combined with other words, create images that do not contradict the author's idea, thereby recreating a single poetic world of the original.

Thus, it should be noted that the primary task of the translator of Uzbek poetry is to recreate each image-symbol of the original, which has its own characteristics and carries a multifaceted meaning. Also, the image system of Uzbek poetry is distinguished by its refinement, where everything is interconnected and almost every word, every artistic detail is undoubtedly an important part of the whole - a unique poetic world of Uzbek literature.

$$
* * *
$$

